\title{
Application of neutral zone concept in order to improve denture stability in a patient with hemifacial spasm: a case report
}

\author{
Nuri Seo, Bo-Young Ma, Hyun-Pil Lim, Chan Park, and Kwi-Dug Yun* \\ Department of Prosthodontics, School of Dentistry, Chonnam National University, Gwangju 61186, Republic of Korea
}

(Received Sep 21, 2017; Revised version received Oct 12, 2017; Accepted Oct 24, 2017)

\begin{abstract}
Hemifacial spasm is characterized by symptoms of intermittent, irregular and involuntary movements ("twitching") affecting the facial muscles that are controlled by the facial nerves unilaterally - affecting one side of the face only. The demographics of this neurologic problem indicates incidence far more common in females than males, and it is usually seen in the fifth decade of life, or later. Edentulous patients with involuntary movements of facial muscles (such as hemifacial spasm) could encounter difficulties in maintaining the stability of their dentures. Not only would the proper and effective occlusion of thedentures be adversely affected, the harmony and compatibility with surrounding tissues (critical factors to be considered in any effort to fabricate a stable set of dentures) could be significantly degraded. This case report will therefore present and advance the concept of fabrication of complete - and completely stable and wellfitting - dentures incorporating the concept of Neutral Zone.
\end{abstract}

KEY WORDS: Complete denture, External impression, Hemifacial spasm, Neutral zone

\section{서 론}

편측안면 경련(hemifacial spasm)은 안면신경 지배 영역 의 근육의 간헐적, 돌발적, 불수의적인 수축에 의하여 발 생하는 반측안면의 운동 기능 항진의 증상을 말하는 것으 로 여성에서 발병빈도가 높으며 주로 50 세 이상에서 발병 한다[1]. 무치악 환자에서 안면경련과 같은 안면근육의 불 수의적인 움직임은 의치의 유지와 안정을 어렵게 할 수 있 다. 이러한 경우 안정적인 의치를 제작하기 위해서는 의치 의 교합뿐 아니라 주변 근육조직과의 조화가 중요한 요소 가 될 수 있고, 이를 위해서 인공치의 위치와 연마면 형태 를 적절히 형성하는 것이 필요하다[2]. 중립대(neutral zone)는 혀가 밖으로 미는 힘과 볼과 입술이 안으로 미는 힘이 평형을 이루는 근신경계 기능에 의한 잠재적 영역으 로 정의되며, 총의치의 인공치가 이 영역에 위치되고, 연 마면 형태가 동적인 근육의 해부학적 형태를 따른다면 근 육의 움직임은 의치를 안정시키는 요소로 작용할 뿐 아니

*Corresponding author: Kwi-Dug Yun

Department of Prosthodontics, School of Dentistry, Chonnam National University, 33 Yongbong-ro, Buk-gu, Gwangju 61186, Republic of Korea Tel.: +82-62-530-5638, Fax: +82-62-530-5639

E-mail: ykd@jnu.ac.kr
라 안면 지지를 통하여 심미성 또한 향상될 수 있다는 장 점이 있다[3].

본 증례는 편측안면 경련을 가진 무치악 환자에서 중립 대 개념을 적용하여 총의치를 제작하였고, 만족할 만한 결 과를 얻었다.

\section{증례보고}

본 증례의 환자는 80 세 여성으로 기존에 사용하던 상하 악 총의치를 분실하여, 의치를 다시 제작하고 싶다는 주소 로 내원하였고, 내원 시 우측 눈에서부터 입술 주위까지 간헐적인 경련 증상을 가지고 있었다(Fig. 1 and 2). 환자 는 고혈압으로 약물 복용 중이었고, 그 밖의 특이할 만한 의과적 병력은 없었다. 환자는 문진 시 편측안면의 경련 증상은 젊은 나이에 발현하였고, 50년 이상 지속되었으며 이 증상의 치료를 위해 병원 진료를 받아본 경험은 없다 고 진술하였다. 무허가업자에게 제작한 의치를 10 년 이상 사용하였으며, 환자는 하악 의치의 헐거움, 특히 안면 경 련 시 의치의 움직임과 잇몸의 통증이 가장 큰 불만이었 다고 하였다.

환자가 전신건강 및 경제적인 이유로 임플란트 식립에 대한 거부감을 갖고 있었기 때문에 치조제 흡수 및 안면 
Nuri Seo et al.

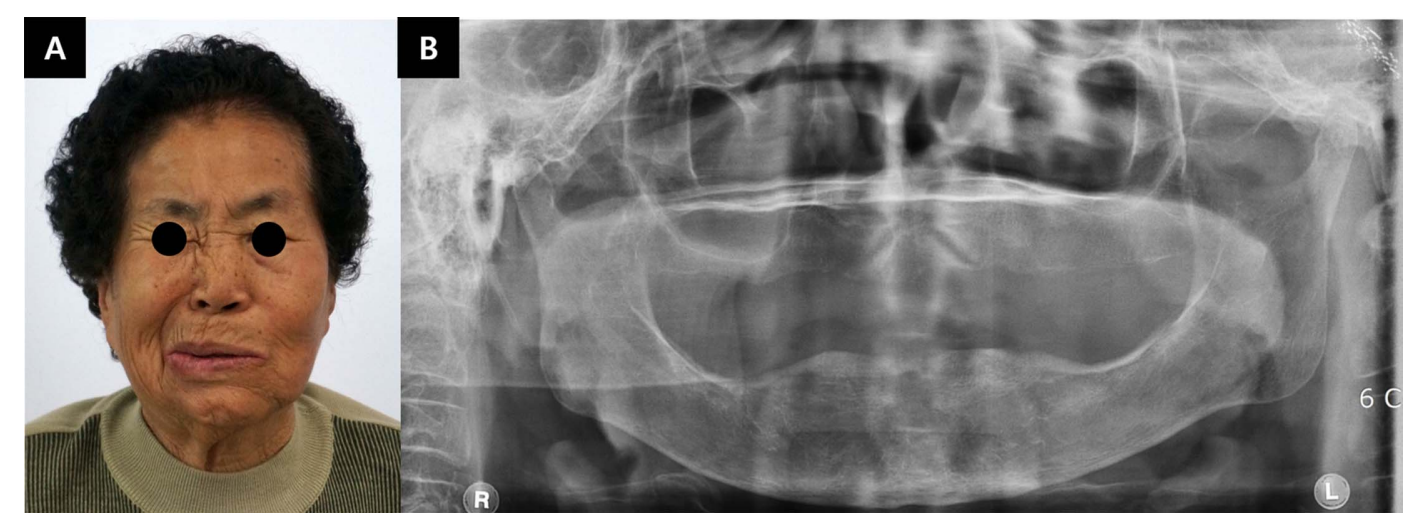

Fig. 1. Initial extraoral photograph (A) and panoramic view (B) at first visit.

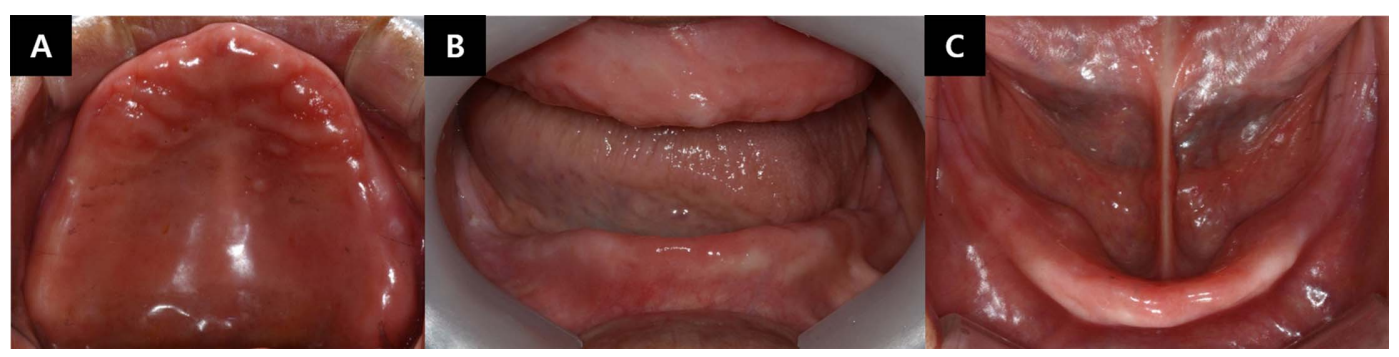

Fig. 2. Initial intraoral photographs (A) Occlusal view of maxilla, (B) Frontal view, (C) Occlusal view of mandible.

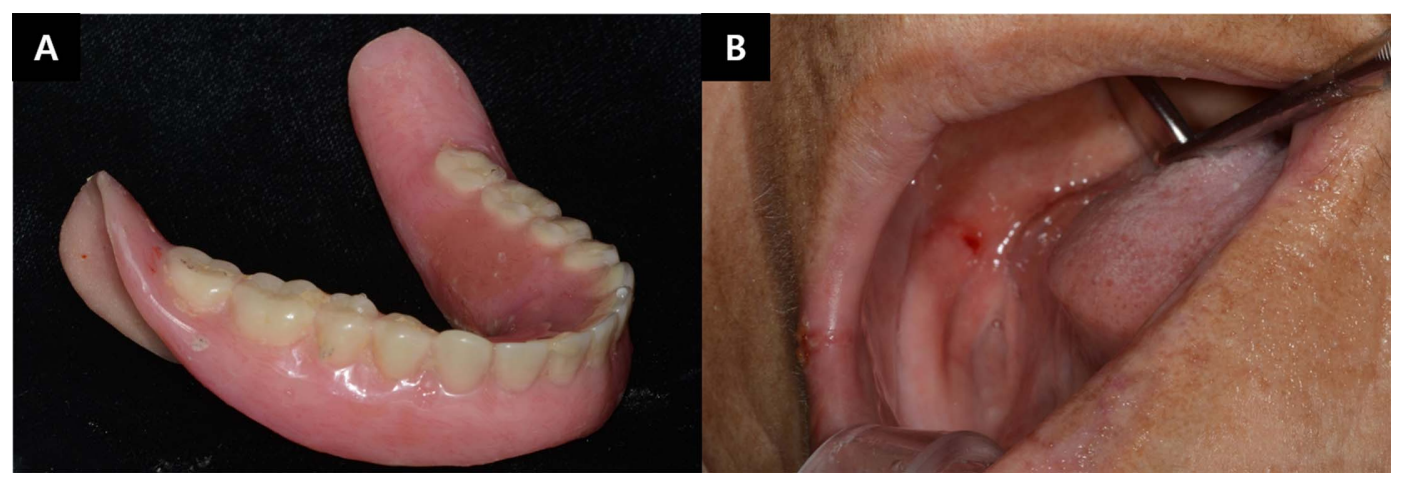

Fig. 3. (A) Lower provisional denture, (B) Sore spot on distal area of right retromolar pad.

경련 증상으로 인한 유지 및 안정에 있어서 불리함을 고 지하고 전통적인 총의치 수복을 계획하였다. 기존 의치 사 용 시 의치의 잦은 탈락과 구강점막의 통증에 안면경련에 의한 협측 근육과 입술 근육의 불수의적인 수축이 영향을 주었을 것으로 판단되었기 때문에 새로운 의치 제작 시에 협측 근육을 포함한 안면근육의 움직임과 압력을 고려할 필요가 있었다. 최종 의치 제작에 앞서 환자가 기존의 의 치를 분실하였기 때문에 먼저 임시의치를 제작하여 관찰 기간을 갖도록 하였다. 3 개월의 임시의치 장착 기간 동안 우측 협점막과 상악결절의 협측 치은, 우측 하악 치조정과 후구치 융기의 원심측에 통증을 호소하여 여러 번의 의치 조정 과정을 거쳤다(Fig. 3). 주로 안면경련 증상이 있는 우측에서 통증이 나타났고, 따라서 최종 의치 제작 시에는 이러한 문제를 개선하기 위하여 협측과 설측 근육의 압력
이 균형을 이루는 중립대에 치아를 배열하고, external impression을 통해 근육의 움직임을 반영한 형태의 연마면 을 형성하기로 하였다.

알지네이트(Cavex Impressional, CAVEX, Haarlem, Netherland)로 예비 인상 채득하여 진단 모형을 제작하였 고(Fig. 4A and 4D), 진단 모형 상에서 개인 트레이를 제 작하였다. 다음 내원 시 모델링 콤파운드로 변연 형성 후 폴리설파이드(Perlmastic, Kerr Corp., Orange, CA, USA) 를 이용하여 상악과 하악의 기능 인상을 채득하고(Fig. 4B and $4 \mathrm{E}$ ) 최종 모형을 제작하였다(Fig. $4 \mathrm{C}$ and $4 \mathrm{~F}$ ). 최종 모 형 상에서 금속 구조물을 제작한 후 환자에게 시적 시 기 록상과 교합제을 제작하여 고딕 아치 기록법을 이용해 악 간 관계를 채득하였다. 간헐적인 편측 안면경련의 영향을 최소화할 수 있도록 반복적인 고딕 아치 기록을 통해 재 


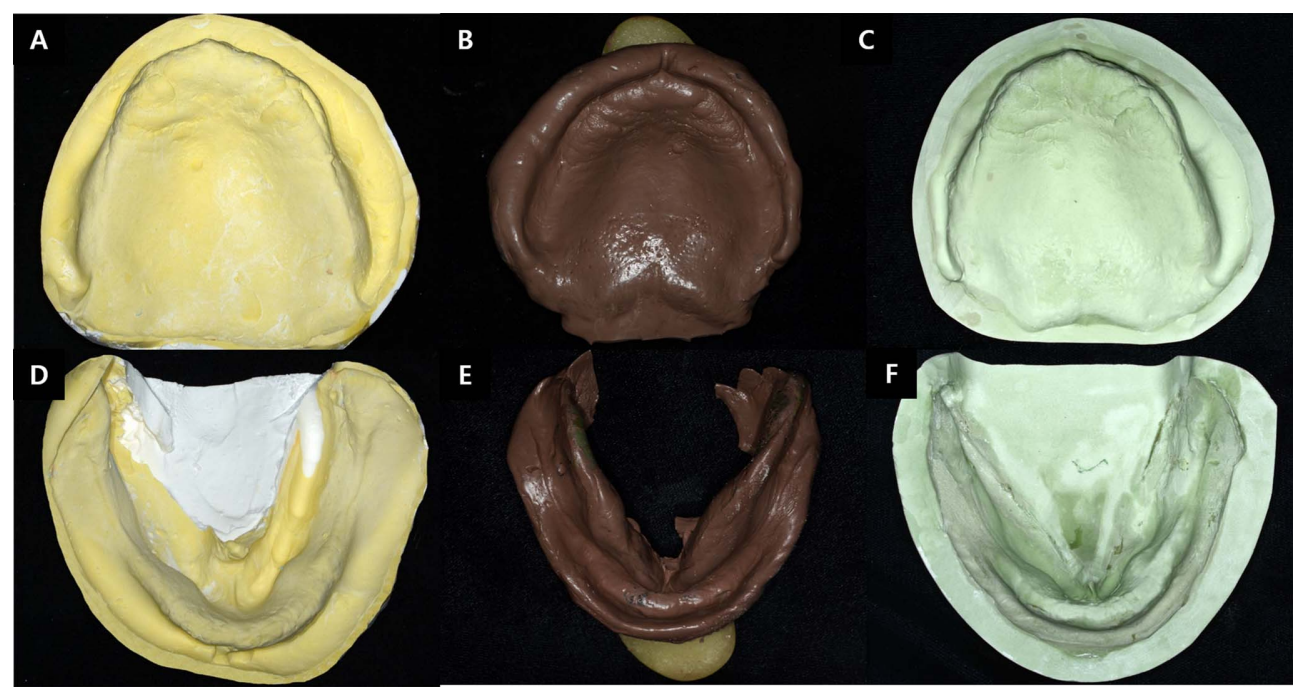

Fig. 4. Diagnostic model (A, D), final impression (B, E) and master cast (C, F).

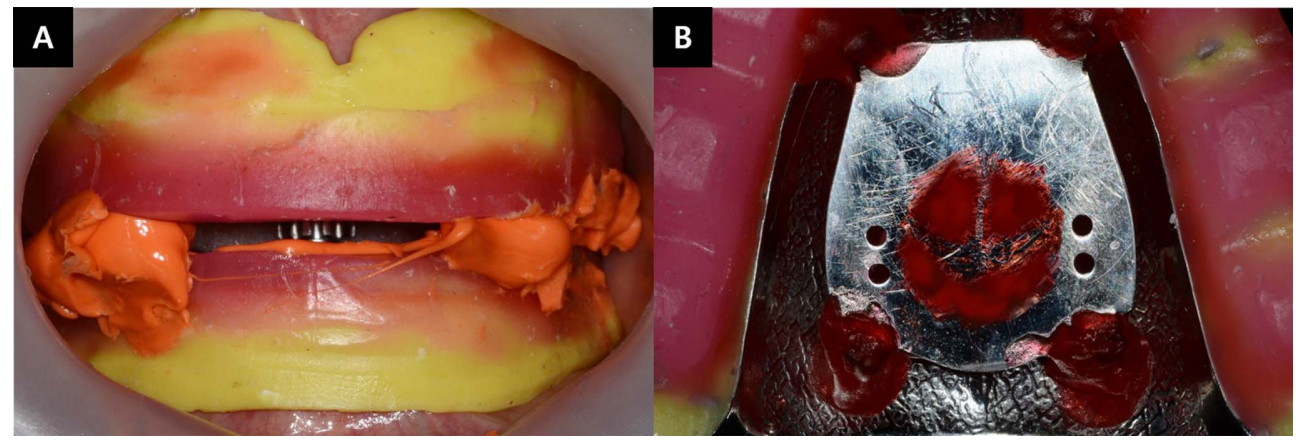

Fig. 5. Vertical dimension (A) and centric relation record using Gothic arch tracing (B).

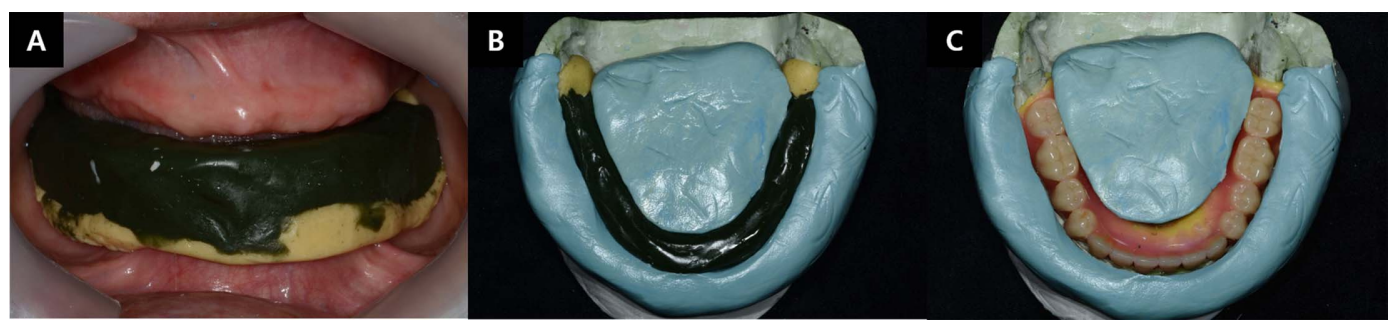

Fig. 6. Recording of neutral zone with compound rim (A), putty index (B), and artificial teeth arrangement according to index (C).

현성 있는 중심위를 채득하였고, 안궁 이전을 시행하여 이 를 반조절성 교합기에 부착하였다(Fig. 5). 이와는 별도로 최종 모형 상에서 아크릴릭 레진으로 기록상를 제작하고 $1.0 \mathrm{~mm}$ wire로 콤파운드 재료를 유지하기 위한 골격을 형 성하였으며, 이후 적절한 온도로 연화시킨 모델링 콤파운 드를 소량씩 적층하면서 환자의 구강 내에서 콤파운드 교 합제를 형성해 주었다. 콤파운드 교합제을 구내에 장착한 동 안 연하, 혀를 내밀거나 입술을 좌우로 핝는 동작, ‘이(E)', '오 $(\mathrm{O})$ ' 발음 등의 기능 운동을 하게 하였다. 콤파운드 교 합제가 경화되는 동안 기능 운동을 반복하여 수행하게 하 였으며 환자의 편측안면 경련 시 근육의 압력 또한 반영
되도록 하였다(Fig. 6A). 형성된 콤파운드 교합제의 형태 를 부가중합형 실리콘 인상재(Exafine Putty Type, GC Corp., Tokyo, Japan)로 인기하여 index를 제작하였고(Fig. $6 \mathrm{~B})$, 이를 기준으로 중립대 내에 치아가 위치할 수 있도록 인공치를 배열하였다(Fig. 6C). 해부학적 치아(Endura, Shofu Inc., Kyoto, Japan)를 이용하여 설측 교합 양식으로 교합을 형성하였고, 완성된 납의치를 환자 구강 내에 시적 하여 교합 및 수직고경을 확인하고 안모 등 심미성을 평 가한 후, 연마면 형성을 위해 외부인상을 시행하였다. 연 마면 인상을 위해 상하악 납의치의 치은 부분 왁스를 부 분적으로 제거하고 부가중합형 실리콘 인상재(Virtual 
Nuri Seo et al.
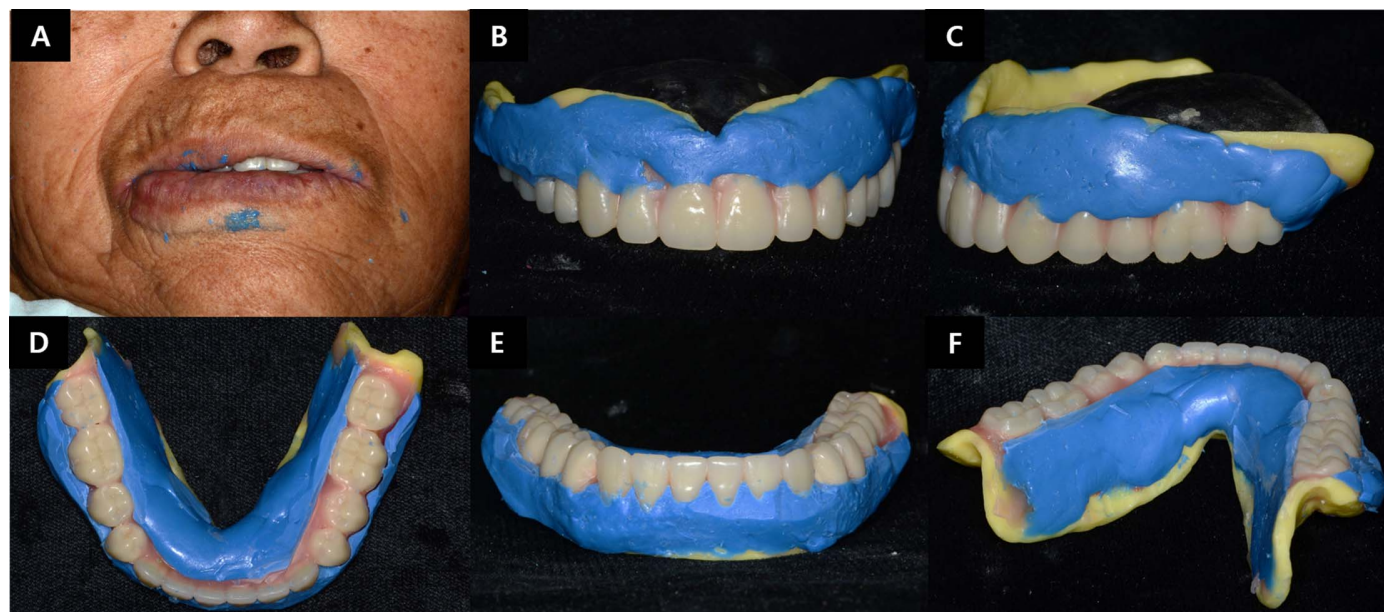

E

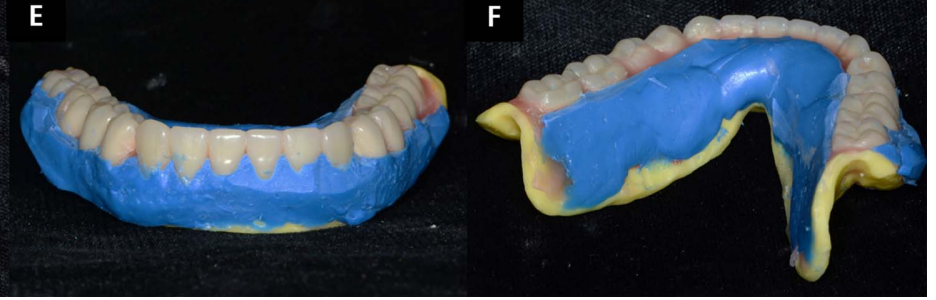

Fig. 7. External impression. Constriction of right facial muscle during impression (A), upper labial flange impression (B), upper buccal flange impression (C), occlusal view of lower impression (D), lower labial impression (E), and lower lingual impression (F).

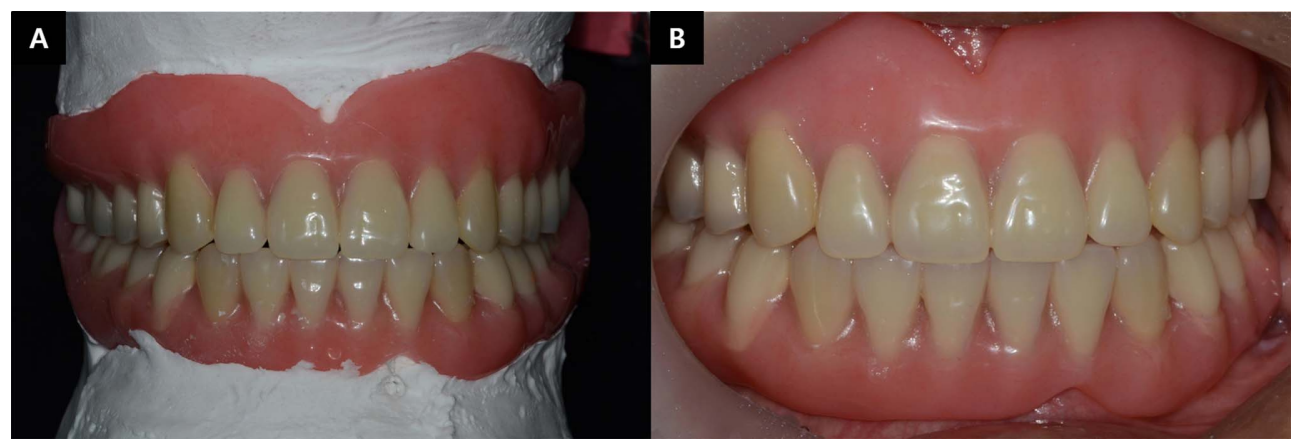

Fig. 8. Clinical remounting (A) definitive denture delivery (B).

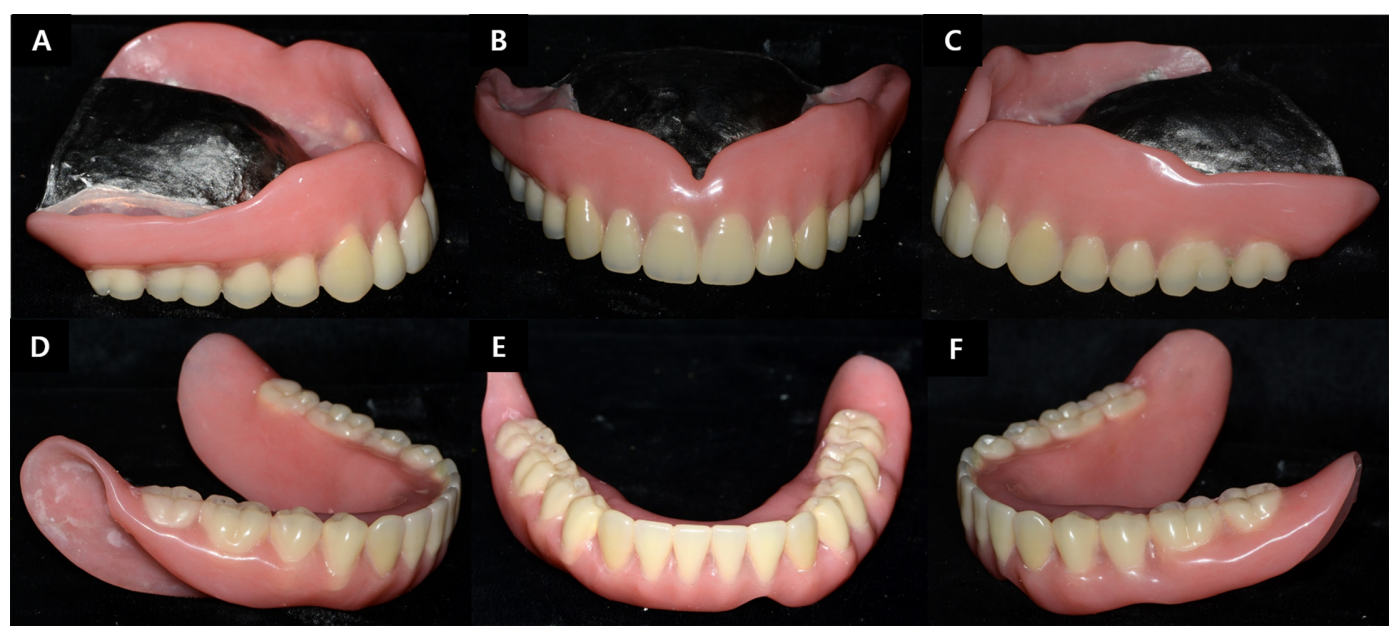

Fig. 9. Definitive prosthesis. Upper complete denture (A, B, and C) and lower complete denture (D, E, and F).

Heavy Body, Ivoclar Vivadent, Liechtenstein)를 적용하여 구강 내에 시적한 후 경화 시간 동안 환자가 기능 운동을 하도록 하였다. 환자의 기능 운동과 편측안면 경련 시 근 육의 움직임을 인기한 연마면을 형성하였다(Fig. 7). 의치 온성 후, 중합 과정의 오차를 수정하기 위한 기공실 재부
착 및 교합 조정을 시행하였고 연마하여 의치를 완성하였 다. 최종 의치를 환자에게 시적하여 의치상의 적합도와 심 미성을 평가하고, 교합 채득 및 안궁 이전하여 진료실 재 부착을 시행한 후 환자에게 장착하였다(Fig. 8).

완성된 새로운 의치는 중립대 개념과 외부인상을 이용 
하여 제작된 연마면의 특징적인 형태를 가지고 있었다 (Fig. 9). 기능 운동 시와 휴식 상태의 안면 경련 시 향상 된 유지와 안정을 보여주었고, 환자 역시 기능적, 심미적 인 면에서 새로운 의치에 대해 만족하였다.

\section{고 찰}

총의치 환자에서 근신경계와의 조화는 안정적인 의치를 제작하기 위한 기본적인 요소이다. 인공치의 위치와 flange의 형태 및 윤곽을 간과하게 되면, 숙련자에 의해 잘 만들어진 의치라 하더라도 종종 불만족스러운 결과를 나 타내기도 한다. 의치 공간의 내부와 외부 경계를 형성하는 연조직이 작용하는 힘은 의치의 안정에 큰 영향을 미친다. 총의치에서 중립대를 통한 접근법의 핵심 개념은 무치악 환경에서 의치의 탈락을 막고 안정화시킬 수 있도록 근육 들의 힘이 작용하는 영역에 인공치를 위치시키는 것이다.

중립대는 혀, 입술, 볼에 의해 형성되며 근육 활성과 습 관은 평생에 걸쳐 발달된다. 치아가 상실되고 나면 근육의 기능과 활성은 독립적으로 기능하게 되고 따라서 구강 내 에 위치한 의치에 지대한 영향력을 갖게 된다[3]. 따라서 기존의 자연치 위치에 인공치를 배열하는 것은 의치 제작 에 있어 매우 중요한 요소이며 연마면의 형태 역시 의치 의 안정에 큰 역할을 한다[4]. 일반적으로 의치의 세 가지 면 즉, 인상면, 교합면, 연마면 중에서 술자들이 인상면과 교합면을 중시하는 반면, 연마면은 간과하는 경우가 많다. 특히 치아상실 후 오랜 기간이 경과하여 치조제가 흡수된 환자에서는 의치의 지지 영역이 좁아짐에 따라 인상면의 면적은 감소하고 연마면의 면적은 증가하게 되므로 치조 제가 충분한 환자에 비해 인공치의 위치와 연마면의 형태 는 더 중요한 역할을 하게 된다[3,5]. 연마면은 볼, 입술 그리고 혀와 접촉하고 있으며 해부학적 구조에 기초한다. 따라서 지나치게 두껍거나 근육의 해부학적 형태를 따르 지 않는 의치상은 주변 근육의 영향으로 의치를 쉽게 탈 락시키는 요소가 될 수 있다. 편측안면 경련을 가진 본 증 례의 환자에서와 같이 비정상적인 근육의 수축을 가지는 경우 통상적인 인공치 배열과 연마면 형성 시 근육의 움 직임이 의치의 유지와 안정을 감소시킬 뿐 아니라 지속적 인 의치의 움직임이 치은과 점막을 자극을 야기할 수 있 으므로 임상적 결과를 향상시키기 위해서 중립대 인상기 법이 도움이 될 수 있다[6,7].

본 증례의 환자의 경우 중립대를 인기하고 연마면을 형 성하는 과정 동안 우측 안면의 경련 시 근육의 움직임과
힘을 인공치의 위치와 연마면의 형태에 반영할 수 있었으 며, 완성된 상하악 총의치에서 여러 기능 운동 및 안면경 련 시 보다 향상된 안정과 유지를 보였고 환자도 기능적, 심미적으로 만족하였다.

\section{Conflict of Interest}

The authors declare that they have no competing interests.

\section{ORCID}

$\begin{array}{ll}\text { Nuri Seo } & 0000-0003-0291-6410 \\ \text { Bo-Young Ma } & 0000-0002-8147-056 \text { X } \\ \text { Hyun-Pil Lim } & 0000-0001-5586-1404 \\ \text { Chan Park } & 0000-0000-5729-5127 \\ \text { Kwi-Dug Yun } & 0000-0002-2965-3967\end{array}$

\section{References}

1. Chaudhry N, Srivastava A, Joshi L. Hemifacial spasm: The past, present and future. J Neurol Sci 2015;356:2731. doi: 10.1016/j.jns.2015.06.032.

2. Cagna DR, Massad JJ, Schiesser FJ. The neutral zone revisited: From historical concepts to modern application. J Prosthet Dent 2009;101:405-412. doi: 10.1016/ S0022-3913(09)60087-1.

3. Beresin VE, Schiesser FJ. The neutral zone in complete dentures. J Prosthet Dent 2006;95:93-100. doi: 10.1016/ j.prosdent.2005.10.005.

4. Schiesser FJ. The neutral zone and polished surfaces in complete dentures. J Prosthet Dent 1964;14:854-865. doi: 10.1016/0022-3913(64)90014-9.

5. Atwood DA. Bone loss of edentulous alveolar ridges. J Prosthet Dent 1979;50:11-21. doi: 10.1902/jop.1979.50.4s.11.

6. Rehmann P, Zenginel M, Wostmann B. Alternative procedure to improve the stability of mandibular complete dentures: a modified neutral zone technique. Int J Prosthodont 2012;25:506-508.

7. Mustafa AZ. Effect of the lingual ledge of neutral zone impression on the retention and stability of mandibular complete denture in elders with atrophied alveolar ridge. Tanta Dent J 2015;12:111-118. doi: 10.1016/j.tdj.2015.02.003. 